\title{
Are my Stars from Ireland? Reflections on an Irish- American Experience
}

\author{
Michael Coffey \\ Independent scholar, writer
}

Copyright (c) 2020 by Michael Coffey. This text may be archived and redistributed both in electronic form and in hard copy, provided that the author and journal are properly cited and no fee is charged for access.

This essay has given me a lot of trouble. It is not because I have never reflected on my IrishAmerican experience. To the contrary. I have explored it in myriad ways - from attending the School of Irish Studies in Dublin as an undergraduate, getting an M.A. in Anglo-Irish Studies from Leeds University, editing a book actually titled The Irish in America, all before discovering, at age 50, that my birth parents were very Irish-American indeed, my father, a Gallagher, first-generation from the village of Glenties in Donegal, my mother from a Mayo line of Bradleys. It is true to say that I have in some fashion embraced the Irish-American identity (ask my wife): I look the part, wearing tweed and wool and favoring Guinness; I've read the great poets, from Yeats to Trevor Joyce. Decidedly unmusical, I did nonetheless try once to learn how to play "the bones." I have published a book of poems that sound (alas) Muldoonish, a story about my unknown father loosely based on Book III of Ulysses, and two years ago a book about Samuel Beckett. But today, this issue of identity troubles me immensely. To surmise why this is so is all I can do.

So many times I have worn the green in writing, without question, without doubt, even before I knew my blood lineage. Somehow, I gravitated to a kind of social Irishness, reading the signature of certain things, I suppose; perhaps owing as well to my adoptive father's IrishAmericanness, though he hardly forced the issue. I ended up doing my undergrad degree at the University of Notre Dame (the Fightin' Irish), favored "Irish" bars (met my first wife at a pub called Molly McGuires), and, after settling in New York City and in publishing, made it a point to know the "Irish intelligentsia" here - the McCourts, the Hamills, Mssrs. McCann and Toibin, etc.; and to see every Brian Friel play that came to Broadway (and draw the line at Riverdance). Then, upon retirement from my post at Publishers Weekly, I jumped into the Beckettian community of scholars - ah, there I went astray!

I say it as I hear it. Qua qua on all sides, then. It's how it is.

The noise that attended my thoughts on this subject of Irish-American identity has been loud and confusing. Like many in these (once) United States, I woke up three years ago from a nice little dream in which it seemed identity was a matter of blending in peaceably with others. President Obama said it was so. He said it was who we were. Our strength was in unity, inclusiveness. Not the case today. Now, identity can be a deadly thing, or a salvation. It can spell your exile, your deportation, or recommend you to a clan. It can get you into a job, a school, a marriage, a country, a club. A country club. Your identity is your profile, one of your data points. It's a miserable time for identity. You will target and be targeted. When this state of affairs is not infuriating it is depressing. 
Nonetheless, I made several attempts to run store-bought Tricolor up the flagpole for this essay, whether the somewhat charming story (or so I have been told) of my adoption, the somewhat charming story (I like to think) of getting pummeled on my first night in Dublin, the wonderful arc of being an admirer of Friel's plays early on and then finding that his Ballybeg settings were based on the Glenties of my Gallagher forebears. But all these stories, through which Irishness ran like a stream, grew thin in my telling. I may have told them often enough and to some purpose. But in these times they seem both fraudulent and irrelevant.

In September, I had lunch with a former professor of mine, James Mays, at the National Gallery in Dublin. Professor Mays, who taught us how to read Joyce's Dublin and listen to Beckett's prose, spoke approvingly of the poetry of Thomas MacGreevy. I forget how the topic came up. Perhaps I was asking about the portrait of MacGreevy that must be somewhere in the gallery, of which MacGreevy was once director. I am of course familiar with the powerful friendship between MacGreevy and Beckett; the importance, to the latter, of their discussions on art, not to mention the introductions, courtesy of the older MacGreevy, to Yeats and Joyce; and I am familiar too with MacGreevy's place, alongside Beckett, Denis Devin, and Brian Coffey, in the lonely quartet of Irish "modernists poets" from the 1930s and '40, but I had never looked that closely at MacGreevy's spare output. Professor Mays, when I asked what he thought of MacGreevy's poems, said simply, "brilliant, first rate."

So in the last few months I have read a lot about MacGreevy and all of his poems. I became intrigued by the story of his relationship with Wallace Stevens, details of which I must've known at one time but which struck me this time with some fresh relevance, and perhaps a way out of my essay impasse. Was Stevens's notion of the MacGreevy Irishness wafting westward toward him in Connecticut an example of what "Irish" is to an American? Was this a place to start?

Stevens's poem "Our Stars Come from Ireland," from Auroras of Autumn, is a very strange poem. In it, while "Tom MacGreevy, in America/Thinks of Himself as a Boy," as part one of the poem is titled, it would seem that Stevens, in America, imagines himself in Kerry, in Tarbert, MacGreevy's boyhood village. The poem is full of the sea, "luminously wet," and the nights are "full of green stars." A "thin-stringed music" blows westward "over the top of the Bank of Ireland." This "music" is from MacGreevy's "Homage to Heironymous Bosch," and the grotesque, Boschian images in the poem have more to do with the hanging of the teenage Irish republican Kevin Barry than what Stevens made of it all, a bizarre intercourse between America and Ireland, West and East, "Gaeled and fitful-fangled darknesses/ Made suddenly luminous, themselves a change,/ An east in their compelling westwardness." We must believe Stevens when he writes "...the whole habit of mind was changed," the poem's penultimate line, which he backed up in effusive letters - "I am sure that ... one is never bored in Dublin because with all the saints they know, and know of, there, there is always company of a kind and in Dublin saints are the best company in the world."

What Stevens saw in his Irish correspondent was a talent for friendship, a Catholic faith, a love of art and music, and a deep connection to the rural. He didn't see the history. He saw only cliché. A Saint Paddy's Day version of the Irish spirit. These things that Stevens valued in MacGreevy - and by association, in Ireland as seen from New England - Beckett did not. In a sense, Beckett would not identify with any of it.

So I did not find any help in this, that thing that the American Stevens saw as the Irishness of MacGreevy's projections. But in pursuing the issue of the unusually intimate friendship between the two poets, I came to realize what Tom was doing in his poetry: like Brian Coffey, he was looking to the Catholic traditions and art on the continent to locate a tradition to which the Irish imagination might find itself at home.

Other elements of what I already knew began to align themselves in fresh formation, like some new deployment that allowed me to make sense of (or so I tell myself) a couple of 
centuries of Anglo-Irish writing. And it is this:

That writing in Ireland is predominantly about asserting and denying and redefining identity - even inventing it, as with Yeats. In aggregate, it is about taking identity apart, like disarming an apparatus that might kill you. I have understood this almost exclusively in the English language, where the bulk of the literary wars have been fought. I see Yeats's and Lady Gregory's attempts - writing plays in French and translating them into English and then into Irish and then back to English - as an attempt to "recast the Irish imagination in English," as Emilie Morin put it. A much different tack than that taken by MacGreevy, but with a similar motive. There are other examples of identity's premises being disrupted with as much or more intention by other Irish writers, from Joyce's assault on the tradition of prose in English in Ulysses to his further assault on Indo-European language in Finnegans Wake, to Beckett's switch to French after the war, to Michael Hartnett's switch to Irish in his poetry, to the several other Irish poets who wrote only in Irish and the novelists - Eimear McBride and Anna Burns come to mind of late - who write in an English put under great stress by circumstances. You can leave it to the Irish to scratch into the surface of language concerns political, social, sexual, historical.

Identity, I have come to realize, in writing by the Irish - and not to my knowledge, by Irish Americans, by the way - is questioned to the point of being discredited, although the necessity of continually making the point appears inalterable. It is a kind interrogation that cannot end, as long as Ireland retains its history, its ever-present past of domination and rebellion, which it will.

What does it mean to be Irish-American? It is not a legitimate question, though there are no lack of answers, or parades, or AOH chapters or Irish pubs. But my answer, for now, is that it means to have understood what Beckett meant by "the neatness of identifications" being where "the danger lies." Or what Leopold Bloom meant by presenting, under hostile questioning in Barney Kiernan's pub, his idea of a nation: "People living in the same place... or in different places." If you are an American reading Irish poets and novelists, and, unlike Wallace Stevens, reading the history, you cannot possibly, in the end, take identity as anything other than something to be wary of. A principal villain in Anna Burns's Milkman is called by the narrator Somebody McSomebody. That should tell you a good deal about identity in the hearts and minds of the Irish. As an American, one should not "wear the green" without thinking of that.

Michael Coffey has published three books of poems, a fourth in collaboration with his wife, the artist Rebecca Smith; a book of short stories, The Business of Naming Things (2014), and, most recently, a hybrid fiction titled Samuel Beckett Is Closed (2018). He has published scholarly articles in the Journal of Beckett Studies and the Beckett Circle, focusing on performance reviews or reviews of books dealing with Beckett and the visual arts. He will also have a contribution in the forthcoming En Compagnie de Beckett/In the Company of Beckett, edited by Lois Oppenheim et al.

mcoffey606@gmail.com 